CLINICAL STUDY

\title{
Hypothalamic-pituitary-adrenal axis response to the severity of illness in non-critically ill patients: does relative corticosteroid insufficiency exist?
}

\author{
M Michalaki $^{1}$, T Margeli ${ }^{1}$, A Tsekouras ${ }^{1}, \mathrm{C} \mathrm{H}$ Gogos $^{2}$, A G Vagenakis ${ }^{1}$ and V Kyriazopoulou ${ }^{1}$ \\ ${ }^{1}$ Division of Endocrinology, Department of Medicine and ${ }^{2}$ Division of Internal Medicine, University Hospital of Patras, Patras 26500, Greece \\ (Correspondence should be addressed to V Kyriazopoulou; Email: vkyriazopoulou@med.upatras.gr)
}

\begin{abstract}
Objective: Relative corticosteroid insufficiency may be common in critically ill patients and is associated with a poor outcome; however, the response of the hypothalamic-pituitary-adrenal (HPA) axis in nursed patients is not known. Our aim was to evaluate the response of HPA axis to the severity of illness in non-critically ill nursed (NCIN) patients and the clinical outcome.

Subjects and methods: Fifty-six nursed patients who were divided into four groups (stroke, mild disease, sepsis and severe sepsis) as well as a control group $(n=15)$ were studied. At admission (day 1$)$, cortisol and ACTH were measured and a low-dose $(1 \mu \mathrm{g})$ corticotrophin test was performed, followed $2 \mathrm{~h}$ later by a standard-dose $(250 \mu \mathrm{g})$ corticotrophin test. Diurnal variation of cortisol was obtained on day 2 . A second identical set of low-dose and standard-dose corticotrophin tests were performed on day 5 or 6 (recovery phase).

Results: In patients with stroke and severe sepsis, cortisol had the highest values and its diurnal variation was abolished. Dissociation of ACTH and cortisol was found in all patients.

The $\Delta_{\text {max }}$ of cortisol after the 1- $\mu$ g corticotrophin test did not differ among the groups, while after the $250-\mu \mathrm{g}$ corticotrophin test, it was borderline higher in controls. The ratio of responders $\left(\Delta_{\max }\right.$ of cortisol $\geq 9 \mu \mathrm{g} / \mathrm{dl}$ ) to non-responders after 1 - or $250-\mu \mathrm{g}$ corticotrophin test did not differ among patients and controls. All patients had a good outcome without glucocorticoid treatment.

Conclusions: Depending on the severity of illness, mild alterations in the HPA axis occurred. However, relative corticosteroid insufficiency was not confirmed in NCIN patients.
\end{abstract}

European Journal of Endocrinology 162 341-347

\section{Introduction}

Illness of various degrees of severity and hospital care result in a stress response, which is mainly mediated by the hypothalamic-pituitary-adrenal (HPA) axis and the sympathoadrenal system $(1,2)$. Although an increasing number of studies have been performed on the function of the axis during illness $(3,4)$, the effectiveness of the axis in severity of illness with respect to cortisol secretion remains unclear. In addition, the use of cortisol treatment in accordance with the severity of illness, especially in acute phase, is controversial. It remains to be established if the administration of glucocorticoids that improves the outcome of critically ill patients $(5,6)$ also improves the outcome of non-critically ill nursed (NCIN) patients.

A consensus statement was published recently with regard to the diagnosis and management of corticosteroid deficiency in patients with critical illness (critical illness-related corticosteroid insufficiency, CIRCI) by an international task force of the American College of Critical Care Medicine (7). According to the task force, the recommendations for treatment with corticosteroids are limited to septic shock and acute respiratory distress syndrome (ARDS).

CIRCI is caused by adrenal insufficiency and tissue resistance to corticosteroids, and it is characterized by an exaggerated and protracted proinflammatory response (1). The diagnosis of tissue resistance to corticosteroid is difficult (8). According to Annane et al. (9), the best criteria for the diagnosis of adrenal insufficiency in critically ill patients are an increase in total serum cortisol of $<9 \mu \mathrm{g} / \mathrm{dl}$ after the administration of corticotrophin $(250 \mu \mathrm{g})$ or a random total cortisol measurement of $<10 \mu \mathrm{g} / \mathrm{dl}$. However, a current concept by Bornstein (10) suggested that the best available test for the diagnosis of adrenal insufficiency in critical illness is the $1-\mu \mathrm{g}$ corticotrophin stimulation test. However, although this test is more sensitive, it is not accepted by all $(7,9)$.

Review of the extensive literature in this area highlights several important unresolved issues with respect to the function of the HPA axis both in physiological states and under the stress of illness. It is 
not established if the above-mentioned diagnostic criteria for CIRCI could be used in NCIN patients and if the dysfunction of the HPA axis could determine the clinical outcome.

It is well documented that glucocorticoid synthesis and release by the adrenal glands are regulated by the HPA axis. However, the picture has subsequently become more complex, and it seems that although ACTH is essential for this release, alternative pathways exist for the regulation of adrenocortical function. Dissociation between the levels of ACTH and glucocorticoids during foetal, postnatal and adult life has been demonstrated $(11,12)$. In addition, clinical studies report the dissociation of ACTH and glucocorticoid levels in critical illness, inflammation and mental disorders. Cytokines, vasoactive factors and neuropeptides seem to play an important role in the modulation of the adrenal response to severe stress, and act independently of ACTH (12).

There is a need for more research to evaluate the adrenal response to the severity of illness in the acute and recovery phases in NCIN patients to detect if relative corticosteroid insufficiency exists, as well as the need for glucocorticoid treatment.

\section{Subjects and methods}

This is a prospective study performed between September 2007 and October 2008 in the Department of Internal Medicine of the University Hospital of Patras. Fifty-six patients who had been admitted to the hospital were divided into four groups according to the severity of their illness: group 1 comprised ten patients (seven males/three females) with ischaemic stroke as diagnosed by computed tomography. Patients with transient ischaemic attack were excluded. Group 1 patients had a mean age of $68.5 \pm 7.8$ years and a mean body mass index (BMI) of $25.1 \pm 3.2 \mathrm{~kg} / \mathrm{m}^{2}$; group 2 comprised 15 patients (7 males $/ 8$ females) with respiratory or urinary track infections (defined as mild disease) and they had a mean age of $62.4 \pm 13.8$ years and a mean BMI of $27.5 \pm 3.9 \mathrm{~kg} / \mathrm{m}^{2}$; group 3 comprised 20 patients ( 8 males/12 females) with sepsis and they had a mean age of $58.5 \pm 8.9$ years and a mean BMI of $25.6 \pm 5.6 \mathrm{~kg} / \mathrm{m}^{2}$ and group 4 comprised 11 patients ( 5 males $/ 6$ females) with severe sepsis and they had a mean age of $61.3 \pm 9.3$ years and a mean BMI of $26.2 \pm 4 \mathrm{~kg} / \mathrm{m}^{2}$. Fifteen healthy controls (seven males/eight females) were also evaluated (mean age $59.6 \pm 5.1$ years; mean BMI $\left.26.1 \pm 2.2 \mathrm{~kg} / \mathrm{m}^{2}\right)$. The controls (group 5) were recruited from the endocrinology outpatient clinic, and were mainly staff members, relatives or friends who were exposed to the stressful conditions of the hospital.

Sepsis was defined as the clinical syndrome of systemic inflammatory response (SIRS) with suspected or proven microbial aetiology. SIRS was diagnosed based on two or more of the following conditions: fever (temperature $>38^{\circ} \mathrm{C}$ ) or hypothermia (temperature $\left.<36^{\circ} \mathrm{C}\right)$, tachycardia $(>90$ beats $/ \mathrm{min})$, tachypnoea ( $>24$ breaths/min), leucocytosis or leucopaenia (white blood cells $>12000$ or $<4000$ cells $/ \mu$ respectively) or immature neutrophils (bands $>10 \%$ ) (13). Severe sepsis was defined as sepsis with one or more signs of organ dysfunction as follows: i) Cardiovascular: arterial systolic blood pressure $\leq 90 \mathrm{mmHg}$ or mean arterial pressure $\leq 70 \mathrm{mmHg}$ that responded to administration of intravenous fluid. ii) Renal: urine output $<0.5 \mathrm{ml} / \mathrm{kg}$ per $\mathrm{h}$ for $1 \mathrm{~h}$ despite adequate fluid resuscitation. iii) Respiratory: $\mathrm{PaO}_{2} / \mathrm{FiO}_{2} \leq 250$ or, if the lung was the only dysfunctional organ, $\leq 200$. iv) Haematological: platelet count $<80000 / \mu \mathrm{l}$ or $50 \%$ decrease in platelet count from the highest value recorded over the previous 3 days. v) Unexplained metabolic acidosis: a $\mathrm{pH} \leq 7.30$ or a base deficit $\geq 5.0 \mathrm{mEq} / \mathrm{l}$ and a plasma lactate level $>1.5$ times the upper limit of normal for the reporting laboratory. vi) Adequate fluid resuscitation: pulmonary artery wedge pressure $\geq 12 \mathrm{mmHg}$ or central venous pressure $\geq 8 \mathrm{mmHg}$ (13). Severe sepsis was evaluated using the sepsis-related organ failure assessment (SOFA) score (14).

No patients had a history of adrenal insufficiency and they had not received any drug known to affect the HPA axis such as rifampicine $(15,16)$, ketoconazole (17), or other antifungal agents or anticonvulsants (18). The patients did not receive corticosteroids, including inhaled preparations, or catecholamines during the study.

Informed written consent was obtained, and the study protocol was approved by the ethics committee of the hospital.

\section{Study design}

On admission (day 1), a blood count and biochemical tests were performed, and baseline serum samples for cortisol, triiodothyronine $\left(\mathrm{T}_{3}\right)$, thyroxine $\left(\mathrm{T}_{4}\right)$, and TSH, and a plasma sample for ACTH were obtained from each patient (baseline values). Also on admission, each patient had undergone a low-dose $(1 \mu \mathrm{g})$ corticotrophin test and $2 \mathrm{~h}$ later a standard-dose $(250 \mu \mathrm{g})$ corticotrophin test (tetracosactrin $0.25 \mathrm{mg}$, Synacthen; Ciba-Geigy, Rueil-Malmaison, France). The tests were performed as follows: after a baseline serum cortisol concentration was drawn, the low-dose corticotrophin test was performed by administering $1 \mu \mathrm{g}$ corticotrophin intravenously. Samples for the measurements of serum cortisol were obtained at 30 (t30) and 60 (t60) minutes after injection. Two hours after the low-dose corticotrophin test, the standard-dose $(250 \mu \mathrm{g})$ corticotrophin test was performed by administering $250 \mu \mathrm{g}$ corticotrophin intravenously. Samples for the measurements of serum cortisol were taken at t30 and t60 (19). The cortisol response $\left(\Delta_{\max }\right)$ was defined as the highest cortisol concentration at $\mathrm{t} 30$ or $\mathrm{t} 60$ minus the baseline 
serum cortisol. Responders were classified as patients with $\Delta_{\max }>9 \mu \mathrm{g} / \mathrm{dl}$, and non-responders were classified as the subjects with $\Delta_{\max } \leq 9 \mu \mathrm{g} / \mathrm{dl}$.

On day 2, samples were collected from each patient for the measurements of serum cortisol at 0800, 1400, 2000 and $0200 \mathrm{~h}$.

Healthy controls who attended the hospital for 1 day underwent identical low-dose $(1 \mu \mathrm{g})$ and standard-dose $(250 \mu \mathrm{g})$ corticotrophin tests.

Three out of the 11 patients with severe sepsis (group 4 ) died on day 3 or 4 . These patients were transferred to the intensive care because of the deterioration of their condition after admission, and no further tests were performed after day 1 .

On day 5 or 6 of nursing, during recovery, 7 of 20 patients with sepsis (group 3) and the 8 survivors with severe sepsis (group 4) were tested again with the low-dose $(1 \mu \mathrm{g})$ and standard-dose $(250 \mu \mathrm{g})$ corticotrophin tests.

\section{Assays}

Serum samples were centrifuged immediately, aliquoted and stored at $-70{ }^{\circ} \mathrm{C}$ until assayed. Plasma samples for the measurement of ACTH were collected under chilled conditions and centrifuged in a cooled centrifuge. Serum cortisol, thyroid hormones and plasma ACTH were measured by chemiluminescence immunoassay (Modular Analytics E170, Roche, and Hitachi). The samples were assayed in a single large batch. For cortisol, the within- and between-run coefficient of variation $(\mathrm{CV})$ values were $1.5-1.7$ and $1.8-2.8 \%$, and the lower detection limit was $0.018 \mu \mathrm{g} / \mathrm{dl}$. For ACTH, the within- and between-run $\mathrm{CV}$ values were 0.6-2.7 and $3.5-5.4 \%$, and the lower detection limit was $1.0 \mathrm{pg} / \mathrm{ml}$. For $\mathrm{T}_{3}, \mathrm{~T}_{4}$ and $\mathrm{TSH}$ respectively the within- and between-run CV values were 1.5-3.1 and
$1.3-1.7 \%, 1.1-3.0$ and $3.7-4.5 \%$ and $3.4-4.2$ and $3.3-7.2 \%$ and the lower detection limits were $0.195 \mathrm{ng} / \mathrm{ml}, 0.42 \mu \mathrm{g} / \mathrm{dl}$ and $0.005 \mu \mathrm{U} / \mathrm{ml}$.

\section{Statistical analysis}

All values are expressed as the mean \pm s.D., and statistical significance was set at $P<0.05$. Mean values were compared between groups by one-way ANOVA and post hoc analysis using the Bonferroni multiple comparison test, or independent-samples t-tests. Mean values within groups were compared by ANOVA for repeated measurements or paired $t$-tests. For categorical variables, comparisons between groups were performed using the $\chi^{2}$ or Fisher's exact test. Pearson's correlation tests were used to assess the relationships among several parameters. Data were analyzed with the use of SPSS version 16 (SPSS, Inc., Chicago, IL, USA).

\section{Results}

\section{Baseline measurements and low-and standard-dose corticotrophin tests on day 1}

No differences were detected among the groups with respect to age, BMI or gender. Baseline measurements from all groups are presented in Table 1. Mean serum ACTH levels did not differ among the groups, but the mean serum cortisol levels were significantly different (one-way ANOVA, $P<0.001$ ). Post hoc analysis revealed that the mean cortisol levels in group 4 were higher than those in groups 2,3 and $5(P<0.001)$, but they did not differ from that in group 1 . Mean albumin levels differed among groups (one-way ANOVA, $P<0.001$ ), and the lowest value was obtained in group 4 (post hoc analysis, $P<0.001$ ). Mean serum $\mathrm{T}_{4}$ and TSH did not differ among the groups, whereas the $\mathrm{T}_{3}$ levels were

Table 1 Baseline characteristics and cortisol response to low and standard doses of ACTH in five groups of participants at admission (day 1).

\begin{tabular}{|c|c|c|c|c|c|c|}
\hline & $\begin{array}{c}\text { Ischaemic } \\
\text { stroke (group 1; } \\
n=10)\end{array}$ & $\begin{array}{l}\text { Mild disease } \\
\text { (group 2; } \\
n=15)\end{array}$ & $\begin{array}{c}\text { Sepsis } \\
\text { (group 3; } \\
n=20 \text { ) }\end{array}$ & $\begin{array}{l}\text { Severe sepsis } \\
\quad \text { (group 4; } \\
n=11)\end{array}$ & $\begin{array}{c}\text { Controls } \\
\text { (group 5; } \\
n=15 \text { ) }\end{array}$ & $\boldsymbol{P}$ \\
\hline Cortisol ( $\mu \mathrm{g} / \mathrm{dl})$ & $24.4 \pm 9.37$ & $19.7 \pm 6.5$ & $21.8 \pm 7.1$ & $38.01 \pm 24.9$ & $13.1 \pm 5.9$ & $<0.001$ \\
\hline ACTH $(\mathrm{pg} / \mathrm{ml})$ & $13.6 \pm 9.7$ & $14.7 \pm 10.5$ & $18.3 \pm 7.2$ & $11.2 \pm 12.7$ & $19.3 \pm 10.6$ & NS \\
\hline $\mathrm{T}_{3}(\mathrm{ng} / \mathrm{ml})$ & $0.9 \pm 0.3$ & $0.9 \pm 0.2$ & $0.8 \pm 0.19$ & $0.58 \pm 0.12$ & $1.3 \pm 0.24$ & $<0.001$ \\
\hline $\mathrm{T}_{4}(\mu \mathrm{g} / \mathrm{dl})$ & $8.2 \pm 1.3$ & $8.9 \pm 1.4$ & $7.4 \pm 1.7$ & $7.8 \pm 2.0$ & $8.2 \pm 1.7$ & NS \\
\hline $\mathrm{TSH}(\mu \mathrm{U} / \mathrm{ml})$ & $1.6 \pm 1.1$ & $1.3 \pm 1.2$ & $0.98 \pm 0.6$ & $1.5 \pm 1.4$ & $1.9 \pm 1.02$ & NS \\
\hline Albumin (g/dl) & $3.7 \pm 0.5$ & $3.6 \pm 0.4$ & $3.5 \pm 0.5$ & $2.5 \pm 0.6$ & $4.4 \pm 0.2$ & $<0.001$ \\
\hline$\Delta_{\max -1 \mu \mathrm{g} \mathrm{ACTH}}(\mu \mathrm{g} / \mathrm{dl})$ & $12.3 \pm 6.9$ & $10.9 \pm 4.9$ & $10 \pm 4.1$ & $10.06 \pm 5.06$ & $13.8 \pm 4.6$ & NS \\
\hline$\Delta_{\max -250 \mu \mathrm{g} \mathrm{ACTH}}(\mu \mathrm{g} / \mathrm{dl})$ & $21.7 \pm 9.2$ & $18 \pm 7.1$ & $17.01 \pm 6.6$ & $16.35 \pm 7.8$ & $23.9 \pm 8.5$ & 0.05 \\
\hline $\begin{array}{l}\text { Responders/non-responders } \\
\text { after } 1 \mu \mathrm{g} \text { ACTH }\end{array}$ & $7 / 3$ & $9 / 6$ & $12 / 8$ & $7 / 4$ & $1 \overline{3} / 2$ & NS \\
\hline $\begin{array}{l}\text { Responders/non-responders } \\
\text { after } 250 \mu \mathrm{g} \mathrm{ACTH}\end{array}$ & $9 / 1$ & $15 / 0$ & $18 / 2$ & $9 / 2$ & $15 / 0$ & NS \\
\hline
\end{tabular}

Group 1, ischaemic stroke; group 2, mild disease; group 3, sepsis; group 4, severe sepsis; group 5, controls. $\Delta_{\text {max }}$ of cortisol maximum-cortisol baseline;

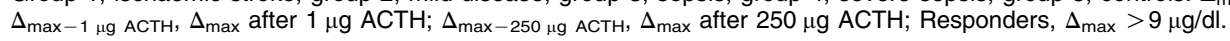


significantly different (one-way ANOVA, $P<0.001$ ). Post hoc analysis showed that the mean $\mathrm{T}_{3}$ levels in group 4 were lower than those in the other groups $(P<0.05$ and $P<0.001$ respectively $)$.

Mean serum cortisol levels at the baseline did not correlate with the mean ACTH levels in all groups of patients, but they did correlate with the SOFA score in group 4 (Pearson $r=0.77, P<0.001$ ), and they were inversely correlated with the mean $\mathrm{T}_{3}$ levels in all patient groups (Pearson $r=-0.39, P<0.001$ ).

The $\Delta_{\max }$ of cortisol after the $1-\mu \mathrm{g}$ corticotrophin test did not differ among the groups. However, the differences in $\Delta_{\max }$ of cortisol after the $250-\mu \mathrm{g}$ corticotrophin test were borderline significant $(P=0.05)$. The $\Delta_{\max }$ of cortisol after the $250-\mu \mathrm{g}$ corticotrophin test tended to be higher in the control group than in patients with sepsis or severe sepsis (independent-samples $t$-test, $P<0.05$ ).

The $\Delta_{\max }$ of cortisol was higher after the $250-\mu \mathrm{g}$

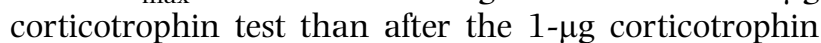
test in all groups of patients (paired $t$-tests, $P<0.001$ ) and in healthy controls (paired $t$-tests, $P<0.01$ ). The $\Delta_{\max }$ of cortisol was inversely correlated with baseline cortisol after the 1 and $250-\mu \mathrm{g}$ corticotrophin tests. (Pearson $r=-0.475, P<0.001$; Pearson $r=-0.335$, $P<0.05$ respectively).

Baseline characteristics of the responders and nonresponders in all groups for both low- and standarddose corticotrophin tests are presented in Table 1.

The baseline characteristics of the three patients with severe sepsis who died on the 3rd and 4th days of hospitalization are presented in Table 2.

During nursing, none of the patients developed hypotension or any electrolyte disorders.

\section{Circadian rhythm}

The diurnal variation in serum cortisol disappeared in groups 1 and 4, but it was maintained in groups 2 and 3 (Table 3). In the four groups of patients, the mean serum cortisol at midnight was $>2.5 \mu \mathrm{g} / \mathrm{dl}$, which is the normal level of cortisol in subjects who are awake (20).

Table 2 Baseline characteristics and cortisol response to low and standard doses of ACTH at admission (day 1 ) in three non-survivors with severe sepsis (group 4).

\begin{tabular}{lccl}
\hline & Patient 1 & Patient 2 & Patient 3 \\
\hline Cortisol $(\mu \mathrm{g} / \mathrm{dl})$ & 41.5 & 63.4 & 100.5 \\
$\mathrm{ACTH}(\mathrm{pg} / \mathrm{ml})$ & 14.8 & 1.02 & 1.00 \\
$\mathrm{~T}_{3}(\mathrm{ng} / \mathrm{ml})$ & 0.41 & 0.42 & 0.6 \\
$\mathrm{~T}_{4}(\mu \mathrm{g} / \mathrm{dl})$ & 8.1 & 7.7 & 4.1 \\
$\mathrm{TSH}(\mu \mathrm{U} / \mathrm{ml})$ & 0.76 & 0.82 & 0.005 \\
$\mathrm{Albumin}(\mathrm{g} / \mathrm{dl})$ & 2.8 & 1.8 & 2 \\
$\Delta_{\max -1 \mu \mathrm{g} \mathrm{ACTH}}(\mu \mathrm{g} / \mathrm{dl})$ & 9.34 & 7.3 & 2.4 \\
$\Delta_{\max -250 \mu \mathrm{g} \mathrm{ACTH}}$ & 17.7 & 6.9 & 1.8 \\
$\quad(\mu \mathrm{g} / \mathrm{dl})$ & & & \\
\hline
\end{tabular}

Table 3 Circadian rhythm of serum cortisol on the first day after admission (day 2) in four groups of patients. ANOVA for repeated measurements was performed in each group. Values are expressed as the mean \pm S.D.

\begin{tabular}{lcccc}
\hline & $\begin{array}{c}\text { Ischaemic } \\
\text { stroke } \\
\text { group 1; } \\
n=10)\end{array}$ & $\begin{array}{c}\text { Mild } \\
\text { disease } \\
\text { (group 2; } \\
n=15)\end{array}$ & $\begin{array}{c}\text { Sepsis } \\
\text { (group 3; } \\
n=20)\end{array}$ & $\begin{array}{c}\text { Severe } \\
\text { sepsis } \\
\text { (group 4; } \\
n=11)\end{array}$ \\
\hline $\begin{array}{c}\text { Cortisol } \\
0800(\mu \mathrm{g} / \mathrm{dl})\end{array}$ & $27.6 \pm 14.6$ & $19.7 \pm 6.9$ & $27.3 \pm 6$ & $48.04 \pm 24.94$ \\
$\begin{array}{c}\text { Cortisol } \\
1400(\mu \mathrm{g} / \mathrm{dl})\end{array}$ & $26.7 \pm 10.1$ & $16 \pm 6.4$ & $23.9 \pm 7.6$ & $42.1 \pm 24.6$ \\
$\begin{array}{c}\text { Cortisol } \\
2000(\mu \mathrm{g} / \mathrm{dl})\end{array}$ & $22.5 \pm 8.4$ & $13.8 \pm 6.5$ & $17.6 \pm 6.4$ & $42.5 \pm 23.8$ \\
$\begin{array}{c}\text { Cortisol } \\
0200(\mu \mathrm{g} / \mathrm{dl})\end{array}$ & $20.6 \pm 10.2$ & $10.3 \pm 5.2$ & $13.7 \pm 5.3$ & $38.9 \pm 25.5$ \\
$P$ & $\mathrm{NS}$ & $<0.001$ & $<0.001$ & $\mathrm{NS}$ \\
\hline
\end{tabular}

\section{Cortisol response to both the low- and standard-dose corticotrophin tests in patients with sepsis and severe sepsis during acute and recovery phases of illness}

On day 5 or 6 during recovery, 7 of 20 patients with sepsis (group 3) and 8 survivors with severe sepsis (group 4) underwent additional testing with the low-dose $(1 \mu \mathrm{g})$ and standard-dose $(250 \mu \mathrm{g})$ corticotrophin tests.

In the patients in group 3, the mean serum cortisol levels were slightly higher in the acute phase than in the recovery phase $(P=0.07)$, whereas the mean plasma ACTH levels did not differ. The $\Delta_{\max }$ of cortisol level after the 1- $\mu$ g corticotrophin test did not differ between the acute phase of illness (day 1) and the recovery phase (day 5 or 6). However, $\Delta_{\max }$ of cortisol after the $250-\mu \mathrm{g}$ corticotrophin test was significantly higher in the recovery phase (Table 4 ).

The patients from group 4 who survived had mean cortisol levels that were higher in the acute phase than in the recovery phase, whereas their mean plasma ACTH and $\Delta_{\max }$ of cortisol after both corticotrophin tests did not differ between the acute and recovery phases (Table 5).

Table 4 Mean cortisol, ACTH, $\Delta_{\max -1 \mu \mathrm{g} \mathrm{ACTH}}$ and $\Delta_{\max -250 \mu \mathrm{g}}$ ACTH at baseline (acute phase) and on the 5th or 6th day of hospitalization (recovery phase) in seven patients with sepsis.

\begin{tabular}{|c|c|c|c|}
\hline & $\begin{array}{l}\text { Acute } \\
\text { phase }\end{array}$ & $\begin{array}{c}\text { Recovery } \\
\text { phase }\end{array}$ & $\boldsymbol{P}$ \\
\hline Cortisol ( $\mu \mathrm{g} / \mathrm{dl})$ & $22.8 \pm 5.8$ & $16.4 \pm 7.7$ & 0.07 \\
\hline ACTH $(p g / m l)$ & $18.1 \pm 9.2$ & $16.5 \pm 7.8$ & NS \\
\hline$\Delta_{\max -1 \mu \mathrm{g} \text { АСТН }}(\mu \mathrm{g} / \mathrm{dl})$ & $9.5 \pm 2.6$ & $11.7 \pm 3.9$ & NS \\
\hline$\Delta_{\max }-250 \mu \mathrm{g} \mathrm{АСТН}(\mu \mathrm{g} / \mathrm{dl})$ & $14 \pm 5.4$ & $19.7 \pm 3.3$ & $<0.001$ \\
\hline $\begin{array}{l}\text { Responders/non- } \\
\text { responders after } \\
1 \mu \mathrm{g} \text { ACTH }\end{array}$ & $4 / 3$ & $5 / 2$ & NS \\
\hline $\begin{array}{l}\text { Responders/non- } \\
\text { responders after } \\
250 \mu \mathrm{g} \mathrm{ACTH}\end{array}$ & $6 / 1$ & $7 / 0$ & NS \\
\hline
\end{tabular}


Table 5 Mean cortisol, ACTH, $\Delta_{\max -1 \mu \mathrm{g} \mathrm{ACTH}}$ and $\Delta_{\max -250 \mu \mathrm{g} \mathrm{ACTH}}$ at baseline (acute phase) and on the 5th or 6th day of hospitalization (recovery phase) in eight survivors with severe sepsis.

\begin{tabular}{lccc}
\hline & $\begin{array}{c}\text { Acute } \\
\text { phase }\end{array}$ & $\begin{array}{c}\text { Recovery } \\
\text { phase }\end{array}$ & $\boldsymbol{P}$ \\
\hline Cortisol $(\mu \mathrm{g} / \mathrm{dl})$ & $26.59 \pm 9.4$ & $18.8 \pm 8.2$ & $<0.05$ \\
$\mathrm{ACTH}(\mathrm{pg} / \mathrm{ml})$ & $11.45 \pm 4.98$ & $20.3 \pm 13.8$ & $\mathrm{NS}$ \\
$\Delta_{\max -1 \mu \mathrm{g} \mathrm{ACTH}}(\mu \mathrm{g} / \mathrm{dl})$ & $11.5 \pm 5$ & $11.3 \pm 3.9$ & $\mathrm{NS}$ \\
$\Delta_{\max -250 \mu \mathrm{g} \text { ACTH }}(\mu \mathrm{g} / \mathrm{dl})$ & $19.2 \pm 5.85$ & $20.04 \pm 8.9$ & $\mathrm{NS}$ \\
$\begin{array}{l}\text { Responders } / \text { non- } \\
\quad \text { responders after }\end{array}$ & $6 / 2$ & $5 / 3$ & $\mathrm{NS}$ \\
$\begin{array}{l}1 \mu \mathrm{g} \text { ACTH } \\
\text { Responders/non- }\end{array}$ & & & \\
$\quad \begin{array}{l}\text { responders after } \\
250 \mu \mathrm{g} \mathrm{ACTH}\end{array}$ & $8 / 0$ & $8 / 0$ & $\mathrm{NS}$ \\
\hline
\end{tabular}

\section{Discussion}

The HPA axis is strongly activated by the stress of illness depending on its severity, and this results in the release of cortisol from the adrenal cortex (1,2 and 7). This activation is crucial for the general adaptation to illness and the maintenance of the physiological response of organs.

Pituitary ACTH is essential for adrenocortical function, but alternative ACTH-independent pathways seem to play a significant role in corticosteroid secretion, especially under conditions of stress. This results in dissociation between plasma levels of ACTH and corticosteroids $(11,12)$.

Numerous recent studies have indicated that neuropeptides, neurotransmitters, cytokines, adipokines and growth factors modulate adrenal glucocorticoid release independently of ACTH, but the exact mechanisms remain unknown (12). Our results are in accordance with the previous observations. This study confirmed the dissociation between plasma ACTH level and serum cortisol level in all four groups of NCIN patients, and a correlation of serum cortisol level with SOFA score was found. This suggests that the cytokines produced in sepsis and severe sepsis are responsible for adrenocortical activation and cortisol production despite the relatively low levels of plasma ACTH.

The mean serum cortisol level at baseline in patients with severe sepsis was significantly higher than that in the other groups of NCIN patients and was positively correlated with SOFA score. They also had a lower level of albumin, which leads to even higher levels of free cortisol (21). This finding indicates an appropriate stimulation of the HPA axis and proportional cortisol production, which are enough for the general adaptation to this specific illness. The fact that the serum cortisol of the three patients with severe sepsis who were transferred to the intensive care unit and died was very high and two of them had $\Delta_{\max }$ of cortisol $<9 \mu \mathrm{g} / \mathrm{dl}$ after the low-dose $(1 \mu \mathrm{g})$ and standard-dose $(250 \mu \mathrm{g})$ corticotrophin tests is interesting. These findings are in accordance with those obtained by Annane (22) who reported that the incidence of mortality is higher in patients with critical illness who have a random cortisol level above $34 \mu \mathrm{g} / \mathrm{dl}$ and $\Delta_{\max }$ of cortisol $\leq 9 \mu \mathrm{g} / \mathrm{dl}$. Our opinion is that such an extremely high level of serum cortisol could be a prognostic criterion for an increased mortality rate in nursed patients with severe sepsis.

The diurnal variation in serum cortisol level was abolished in group 1 which corresponded to patients with ischaemic stroke and group 4 with patients with severe sepsis. High levels of serum cortisol were found in these patients during the day, which was probably a response of the activated HPA axis to the stress of illness. It is remarkable that patients with stroke or severe sepsis have the same response to the stress of illness. In group 2, which corresponded to patients with mild disease, and group 3, which corresponded to patients with sepsis, although a diurnal variation in serum cortisol was maintained, the level of cortisol at midnight remained high compared with that in normal unstressed subjects (20).

We observed that the healthy subjects in the control group had a $\Delta_{\max }$ of cortisol after the 250- $\mu \mathrm{g}$ corticotrophin stimulation test which was marginally higher than that in patients with sepsis or severe sepsis. We speculated what is the level of $\Delta_{\max }$ of cortisol after the 250- $\mu$ g corticotrophin stimulation test expected in disease and particularly in sepsis and severe sepsis taking into account the already maximum stimulation of the HPA axis.

The ratio of responders to non-responders after the low- or standard-dose corticotrophin tests did not differ among the patient groups and healthy controls. This is a finding of high importance, and it supports the fact that the $\Delta_{\max }$ of cortisol $<9 \mu \mathrm{g} / \mathrm{dl}$ after the standarddose corticotrophin test could not be a diagnostic criterion for relative corticosteroid insufficiency in non-critically ill patients. We believe that further studies with a lot of patients with different severity of illness are needed to confirm the appropriate baseline and stimulated cortisol levels in non-critically ill patients, by taking into account the various needs of each patient also, a fact which is very complicated.

The acute stress response during critical illness is characterized by activation of the HPA axis and sympathoadrenal system axis, with increased secretion of cortisol, an increase in the percentage of free cortisol and increased translocation of the GR complex into the nucleus (7). However, there is increasing evidence that in critically ill patients, this pathway may be impaired $(3,23,24)$, but there are scattered data for the NCIN patients. The reported prevalence of adrenal insufficiency in critically ill patients varies widely $(0-77 \%)$. This variation may correlate with the severity of critical illness and depends on the diagnostic criteria used. We believe that depending on the severity of illness, the critical $\Delta_{\max }$ of cortisol of $<9 \mu \mathrm{g} / \mathrm{dl}$ used to define CIRCI could differ among illnesses, especially in non-critically nursed patients, and new diagnostic criteria are needed. 
In the current study, all the patients with severe sepsis who recovered had $\Delta_{\max }$ of cortisol $\geq 9 \mu \mathrm{g} / \mathrm{dl}$ after the standard-dose corticotrophin stimulation test in the acute phase of disease (responders). Two patients with sepsis recovered despite the fact that they had $\Delta_{\max }$ of cortisol $<9 \mu \mathrm{g} / \mathrm{dl}$ after the standard-dose corticotrophin test in the acute phase of disease (nonresponders) without corticosteroid treatment. This fact confirms our opinion that in NCIN patients, the degree of activation of their HPA axis and cortisol production correlates with the severity of their disease and is sufficient for their general adaptation.

We evaluated patients with sepsis and severe sepsis during the acute and recovery phases of illness. In the recovery phase, patients with sepsis had a baseline level of cortisol borderline lower and a significantly higher $\Delta_{\max }$ of cortisol after the standard-dose $(250 \mu \mathrm{g})$ corticotrophin test than in the acute phase, which indicated that the HPA axis was recovering. Patients with severe sepsis had a significantly lower baseline cortisol but a similar $\Delta_{\max }$ of cortisol after the standarddose $(250 \mu \mathrm{g})$ corticotrophin test in the recovery phase as compared to the acute phase. This was probably due to the short interval between the acute and recovery phases and the inability of the HPA axis to recover or probably due to non-reproducibility of these tests during illness (25). The mechanisms that lead to alterations in the HPA axis during illness are complex and still poorly understood.

In conclusion, we believe that mild alterations in the response of the HPA axis occur in NCIN patients, but relative corticosteroid insufficiency could not be established. None of the study patients received glucocorticoid therapy, and all but three patients with severe sepsis, who were transferred to the intensive care unit and died, had a good outcome. Recommendations for the management of septic shock and ARDS with glucocorticoids have been published (7), and we agree with those. A limitation of our study is the relatively small sample size. We need further prospective controlled numerous studies to confirm the effective level of baseline and stimulated cortisol and if corticosteroid treatment is necessary in the acute phase of the disease in NCIN patients. During nursing patients with non-critical illness, physicians must be aware of clinical signs and symptoms that are suspicious for glucocorticoid insufficiency.

\section{Declaration of interest}

The authors declare that there is no conflict of interest that could be perceived as prejudicing the impartiality of the research reported.

\section{Funding}

This work was supported by the Research Committee of the Medical School, University of Patras, Greece. This research did not receive any specific grant from any funding agency in the public, commercial, or not-for-profit sector.

\section{References}

1 Chrousos GP. Stress and disorders of the stress system. Nature Reviews. Endocrinology 20095 374-381.

2 Stratakis CA \& Chrousos GP. Neuroendocrinology and pathophysiology of the stress system. Annals of the New York Academy of Sciences 1995 771 1-18.

3 Widmer IE, Puder JJ, König C, Pargger H, Zerkowski HR, Girard J \& Müller B. Cortisol response in relation to the severity of stress and illness. Journal of Clinical Endocrinology and Metabolism 200590 4579-4586.

4 Dimopoulou I \& Tsagarakis S. Hypothalamic-pituitary dysfunction in critically ill patients with traumatic and nontraumatic brain injury. Intensive Care Medicine 200531 1020-1028.

5 Sprung CL, Annane D, Keh D, Moreno R, Singer M, Freivogel K, Weiss YG, Benbenishty J, Kalenka A, Forst H, Laterre P-F, Reinhart K, Cuthbertson BH, Payen D, Briegel J \& for the CORTICUS Study Group. Hydrocortisone therapy for patients with septic shock. New England Journal of Medicine 2008358 111-124.

6 Annane D, Sébille V, Charpentier C, Bollaert PE, Francois B, Korach JM, Capellier G, Cohen Y, Azoulay E, Troché G, ChaumetRiffaud P \& Bellissant E. Effect of treatment with low doses of hydrocortisone and fludrocortisone on mortality in patients with septic shock. Journal of the American Medical Association $2002 \mathbf{2 8 8}$ 862-871.

7 Marik PE, Pastores SM, Annane D, Meduri GU, Sprung CL, Arlt W, Keh D, Briegel J, Beishuizen A, Dimopoulou I, Tsagarakis S, Singer M, Chrousos GP, Zaloga G, Bokhari F \& Vogeser M. Recommendations for the diagnosis and management of corticosteroid insufficiency in critically ill adult patients: consensus statements from an international task force by the American College of Critical Care Medicine. Critical Care Medicine 200836 1937-1949.

8 Meduri GU \& Yates CR. Systemic inflammation-associated glucocorticoid resistance and outcome of ARDS. Annals of the New York Academy of Sciences $2004 \mathbf{1 0 2 4} 24-53$.

9 Annane D, Maxime V, Ibrahim F, Alvarez JC, Abe E \& Boudou P. Diagnosis of adrenal insufficiency in severe sepsis and septic shock. American Journal of Respiratory and Critical Care Medicine $2009 \mathbf{1 7 4}$ $1319-1326$.

10 Bornstein SR. Predisposing factors for adrenal insufficiency. New England Journal of Medicine $2009 \mathbf{3 6 0} 2328-2339$.

11 Bornstein SR \& Chrousos GP. Adrenocorticotropin (ACTH)- and non-ACTH-mediated regulation of the adrenal cortex: neural and immune inputs. Journal of Clinical Endocrinology and Metabolism 199984 1729-1736.

12 Bornstein SR, Engeland WC, Ehrhart-Bornstein M \& Herman JP. Dissociation of ACTH and glucocorticoids. Trends in Endocrinology and Metabolism 200819 175-180.

13 Levy MM, Fink MP, Marshall JC, Abraham E, Angus D, Cook D, Cohen J, Opal SM, Vincent JL \& Ramsay G. 2001 SCCM/ESICM /ACCP/ATS/SIS International Sepsis Definitions Conference. Intensive Care Medicine 200329 530-538.

14 Ferreira FL, Bota DP, Bross A, Mélot C \& Vincent JL. Serial evaluation of the SOFA score to predict outcome in critically ill patients. Journal of the American Medical Association 2001286 1754-1758.

15 Kyriazopoulou V, Parparousi O \& Vagenakis AG. Rifampicininduced adrenal crisis in adisonian patients receiving corticosteroid replacement therapy. Journal of Clinical Endocrinology and Metabolism 198459 1204-1206.

16 Kyriazopoulou V \& Vagenakis AG. Abnormal overnight dexamethasone suppression test in subjects receiving rifampicin therapy. Journal of Clinical Endocrinology and Metabolism 1992 75 315-317.

17 Iranmanesh A, Ovetsky RM, Lizarralde G \& Schleupner CJ. Effect of ketoconazole on the 11-hydroxylation step of adrenal steroidogenesis. Southern Medical Journal 198780 725-728. 
18 Baxter J \& Tyrrell B. The adrenal disease. In Endocrinology and Metabolism, edn 2, ch 12, pp 511-650. Eds P Felig, J Baxter, A Broadus \& L Frohman. New York: McGraw-Hill Book Company, 1987.

19 Marik PE \& Zaloga GP. Adrenal insufficiency during septic shock. Critical Care Medicine 200331 141-145.

20 Weitzman ED, Fukushima D, Nogeire C, Roffwarg H, Gallagher TF \& Hellman L. Twenty-four hour pattern of the episodic secretion of cortisol in normal subjects. Journal of Clinical Endocrinology and Metabolism 197133 14-22.

21 Hamrahian AH, Oseni TS \& Arafah BM. Measurements of serum free cortisol in critically ill patients. New England Journal of Medicine $20043501629-1638$.

22 Annane D, Sébille V. Troché G, Raphaël JC, Gajdos P \& Bellissant E. A 3-level prognostic classification in septic shock based on cortisol levels and cortisol response to corticotropin. Journal of the American Medical Association 2000283 1038-1045.
23 Vogeser M, Groetzner J, Küpper C \& Briegel J. Free serum cortisol during the postoperative acute phase response determined by equilibrium dialysis liquid chromatography-tandem mass spectrometry. Clinical Chemistry and Laboratory Medicine 2003 41 146-151.

24 Ho T, Al-Musalhi H, Chapman MJ, Quach T, Thomas PD, Bagley CJ, Lewis JG \& Torpy DJ. Septic shock and sepsis: a comparison of total and free plasma cortisol levels. Journal of Clinical Endocrinology and Metabolism 200691 105-114.

25 Loisa P, Uusaro A \& Ruokonen E. A single adrenocorticotropic hormone stimulation test does not reveal adrenal insufficiency in septic shock. Anesthesia and Analgesia 2005101 1792-1798.

Received 26 October 2009

Accepted 9 November 2009 